\title{
Complementary therapies in education, community extension and research in nursing
}

\author{
Terapias complementares na educação, extensão comunitária e pesquisa em enfermagem
}

Terapias complementarias en la educación, extensión comunitaria e investigación en enfermería

'Universidade Federal de São Carlos. São Carlos, São Paulo, Brazil

How to cite this article: Sousa LA, Salim NR, Fumincelli L, Teixeira IMC. Complementary therapies in education, community extension and research in nursing. Rev Bras Enferm. 2021;74(2):e20200449. https://doi.org/10.1590/0034-7167-2020-0449

\section{Corresponding author:}

Natália R. Salim

E-mail: nat.salim@gmail.com

EDITOR IN CHIEF: Dulce Barbosa ASSOCIATE EDITOR: Hugo Fernandes

Submission: 07-06-2020

Approval: 09-26-2020

\section{ABSTRACT}

Objective: Report the implementation of integrative and complementary practices in a Nursing course at a federal university in the fields of teaching, research and extension. Method: As a reference, the concept of nursing care anchored in the integrality and the avant-garde legacy of Florence Nightingale was used. The report is structured in two topics: the first describes the experience itself, and the second brings a critical reflection about the limits, achievements and challenges. Results: The interaction of integrative practices in nursing and its insertion in teaching, research and extension corroborate holistic care, favor the construction of scientific knowledge in the area and potentially requalify professional training. Final considerations: The insertion of integrative and complementary practices in nursing education can contribute to the consolidation of an integral model of care in SUS towards access and comprehensiveness.

Descriptors: Complementary Therapies; Education, Nursing; Community-Institutional Relations; Integrality in Health; Nursing Research.

\section{RESUMO}

Objetivo: Relatar a implementação das práticas integrativas e complementares em um curso de Enfermagem de uma universidade federal nos campos do ensino, pesquisa e extensão. Método: Como referencial, foi utilizado o conceito do cuidado de enfermagem ancorado na integralidade e no legado vanguardista de Florence Nightingale. O relato está estruturado em dois tópicos: o primeiro descreve a experiência em si, e o segundo traz uma reflexão crítica acerca dos limites, conquistas e desafios. Resultados: A interação das práticas integrativas na enfermagem e sua inserção no ensino, pesquisa e extensão corroboram o cuidado holístico, favorecem a construção do conhecimento científico na área e potencialmente requalificam a formação profissional. Considerações finais: $A$ inserção das práticas integrativas e complementares na formação em enfermagem pode contribuir para consolidação de um modelo integral de cuidado no SUS na direção do acesso e da integralidade.

Descritores: Terapias Complementares; Educação em Enfermagem; Extensão Comunitária; Integralidade em Saúde; Pesquisa em Enfermagem.

\section{RESUMEN}

Objetivo: Relatar implementación de prácticas integradoras y complementarias en curso de Enfermería de una universidad federal en los campos de la enseñanza, investigación y extensión. Método: Como referencial, ha utilizado el concepto del cuidado de enfermería ancorado en la integralidad y en legado vanguardista de Florence Nightingale. El relato ha estructurado en dos tópicos: el primer describe la experiencia en si, y el segundo ofrece una reflexión crítica acerca de los límites, conquistas y desafíos. Resultados: La interacción de las prácticas integradoras en la enfermería y su inserción en la enseñanza, investigación y extensión corroboran el cuidado holístico, favorecen la construcción del conocimiento científico en el área y potencialmente recalifican la formación profesional. Consideraciones finales: La inserción de las prácticas integradoras y complementarias en la formación en enfermería pueden contribuir para consolidación de un modelo integral de cuidado en el SUS en la dirección del acceso y de la integralidad.

Descriptores: Terapias Complementarias; Educación en Enfermería; Extensión Comunitaria; Integralidad en Salud; Investigación en Enfermería. 


\section{INTRODUCTION}

Looking at history shows us that women built their own knowledge about care practices, learned through a network of exchanges and the communication of experiences. They were healers, despite being often judged as witches or charlatans. They built the first knowledge about medicinal herbs with their crops and sharing their uses. Historical records show that this type of care, whose bases differ from those of modern medicine, was often the only form of care accessible to the neediest people. These practices that gave rise to the profession of midwife and nurse represented a more human and empirical practice ${ }^{(1)}$.

Such empirical care has contributed to the emergence of nursing as a profession, and the care practices arising from knowledge with medicinal herbs have been translated into care (more recently, holistic and integral) arising from knowledge about the interaction between human beings and nature, with yourself, your habits and customs. Thus, health care with art and science determined the main bases of nursing, whose philosophical, scientific and ethical thinking was described by Florence Nightingale, the pioneer of the profession, already in her time. Thus, the legacy of this theory has contributed and still contributes to the development of care through its practices of observation, research, experience and $\operatorname{art}^{(2)}$.

With her work, Florence left the foundations for nursing care, based on respect and an integral look at the human being. Its records, found in the book "Notes on Nursing", present the roots of the holistic model of care, through visionary reports showing that improvements in health conditions were related to environmental conditions in the treatment and recovery process $^{(3)}$. In comprehensive care, the search for the necessary transformations to improve people's quality of life involves the recovery of subtlety, sensitivity, senses, and can allow the union between subject and action, thus manifesting ways of acting and producing integrality in health ${ }^{(4)}$.

Throughout her work, the nurse's reports about water, air, heat, cold - exemplified in notes such as "keeping the indoor air as clean as possible"; "unnecessary noise creates a negative expectation in the mind, this is harmful to the patient"(5) — show that this knowledge precedes the theories of nursing care legitimized over time, whose holistic bases are closely related to complementary therapies, or integrative and complementary practices, terminology adopted in this article.

Integrative and complementary practices (PICs), a term adopted by the Brazilian government, also known in other countries as "alternative and complementary medicines" or "traditional medicines", are present in 129 countries and are widely discussed and recognized by the World Organization (WHO), with political and technical incentive to be inserted in public health systems, through its document Traditional Medicine Strategy 2014-2023(6).

In Brazil, present in the Unified Health System (SUS), these approaches started to gain visibility with the publication of the National Policy of Integrative and Complementary Practices (PNPIC). Currently, in addition to traditional Chinese medicine/acupuncture, homeopathy, medicinal plants/phytotherapy, anthroposophical medicine, social thermalism/crenotherapy, another 24 therapeutic approaches are part of the PNPIC. The recent expansion, growth and supply of these therapeutic approaches in Brazil and worldwide require constructions for their assessment, in order to point out their limits and explain their effectiveness in care ${ }^{(7)}$. Salles, Homo and Silva $(2014)^{(8)}$, studied the relationship between PICs and care has grown in the field of health; especially in nursing.

Considering the legacy of Florence Nightingale for both nursing and the PICs area, throughout the author's bicentennial celebrations, it is essential to reflect on these therapeutic approaches in the university context and their interface with teaching, assistance, management and popular participation. In this sense, students, teachers, health professionals, managers and users of SUS have the opportunity to interact, dialogue and collectively contribute to the expansion and consolidation of PICs in Primary Health Care services, which imperatively requires their implementation in the context of university education.

Given the above, this article aims to report the experiences of implementing integrative and complementary practices in nursing education in the areas of teaching, research and extension.

\section{OBJECTIVE}

Report the implementation of Integrative and Complementary Practices in a Nursing course at a federal university in the fields of teaching, research and extension.

\section{EXPERIENCE REPORT}

\section{Implementation of Integrative and Complementary Prac- tices in Nursing Education}

The following report is the result of the experiences of four professors from the Federal University of São Carlos, in the municipality of São Carlos, state of São Paulo: three, from the Nursing Department; one, from the Department of Teaching Methodology. Three teachers are nurses, and one is an obstetrician. Three have training and experience in aromatherapy, Shantala, massage, acupuncture and yoga PICs, and another is in management activity as coordinator of the UFSCar Health School Unit (USE), where various activities take place with the PICs. The experiences described in this article have been occurring since 2016, targeting undergraduate students and UFSCar employees, as well as professionals and users of the health services of the Unified Health System, and have presented their experiences in the process of implementing PICs within the scope of teaching, research and extension.

\section{Teaching experience}

The process of implementing PICs in education began in the second semester of 2018. The first activities with these practices were with students in the elective disciplines of the curriculum of the Nursing course. Initially, the subjects were "Women's Health" and "Collective Health" and, later, at the reception of 1st year students (freshers 2019), "Supervised Curricular Internship" and "Elderly Health".

The PICs were part of the closure of the discipline "Women's Health". In a large room, students and teachers sat in a circle on mattresses, held a round of presentation, body and meditative yoga 
practices. Subsequently, a conversation was held about Chinese medicine and herbal medicine in women's health. The meeting ended with an exchange of massage between the students. During the final assessment of the experience, the reports were of renewal and the need to have more moments like that during the semester.

In the discipline "Collective Health", in a small group during immersion in the field "Syntheses, searches and new synthesis", the body and meditative practices of yoga were offered to the group of students by the teacher at the beginning of the first meeting in the classroom, round and practiced standing. In the end, during the evaluation of this meeting, all students reported that they felt very good about body and meditative practice, and that they would like to experience these practices in all meetings. Thus, this experience took place throughout the semester. In the evaluation of the end of the discipline, at the end of the semester, all students considered that this experience contributed in several ways, helping to relax, relieve the stress of everyday life and the overload of the end of the semester.

In relation to freshers 2019, at the invitation of the coordinator of the undergraduate course, the activity took place in a classroom of the department, previously organized with mattresses arranged in a circle, where the group of newcomers could experience the bodily and meditative practices of yoga, the aromatherapy, Thai massage and conversation about PICs, health policies and self-care. At the end of the activity, students were offered a small sample of diluted essential oil, offered by the teachers; they reported that this activity was very welcoming and that they were surprised by the way it happened.

In the discipline "Health Care for the Elderly", PICs were experienced during clinical teaching that takes place twice a week, in health services - in this case, in a Family Health Strategy (FHS) unit. On the first day at the FHS, during a presentation round, meditative practice and conversation about body practice and acupuncture were held. Students, community health workers and nursing technicians expressed interest in these different therapeutic approaches throughout the entire range of clinical teaching through meditative practices, body practices, auriculotherapy and moxibustion therapy.

In the discipline of "Supervised Curricular Internship", as an intervention project for the students' internship, an activity was offered in the form of a tent, a conversation circle on natural gynaecology, with the presentation of herbs and their herbal properties. The activity started with a yoga breathing practice, followed by tea to share among the participants. At the end, self-massage with aromatherapy was offered. Most of them were elderly women, which made it possible to open space for conversation about how much women are burdened with the responsibilities of caring for the home and children and about the importance of finding time and ways for self-care.

Among the educational experiences, it is worth highlighting the experience of the proposal to reformulate the curriculum of the Nursing course. This reformulation focused on the PICs, and their insertion was approved in the new curriculum, as elective disciplines, to be offered in the 1st, 2 nd and 3rd semesters of the Nursing undergraduate course. Thus, in the 1st semester, the discipline "Integral Care and Self-Care" will be offered, related to the introduction of PICs in health care. In subsequent semesters, the disciplines offered, "Comprehensive Care and Integrative Health Practices I" and "Comprehensive Care and Integrative Health Practices II", will deepen the theoretical and practical knowledge about these practices in the context of self-care and health education.

\section{Research experience}

The research-related experiences have as their starting point a project that aims to analyze the process of implementing PICs in Primary Health Care, at the Regional Health Department III (DRS III), which includes São Carlos and 23 other neighboring municipalities in the region. The research has a qualitative approach and is being developed through action research $(A-R)$.

In this direction, since 2019, the opportunity to build genuine partnerships with different SUS professionals involved with the PICs stands out, as well as the participation of the articulators of the quality development center for SUS of the DRS III, as interlocutors between managers and health professionals from the municipalities of DRS III, providing approximations and contributing greatly to the development of partnerships in the process of this A-R.

Although it is a process in the initial construction phase, many fruits can be mentioned during this period: five meetings that took place with different groups of professionals (from the Extended Family Health Centers [NASF], from the different SUS health services and from the municipal PIC commissions in São Carlos and Araraquara); and participation in four meetings of the technical chambers between the municipal managers of the four regions of the DRS III (central region, heart, north and mid-west). In all these meetings, a meditative practice was carried out at the beginning, in which the majority participated, verbalized a feeling of wellbeing and calm and emphasized the importance of PICs in the care and self-care of families served in health services and health professionals in the SUS.

Three important marks in the experiences in the scope of the research are the consequences of this A-R: 1) the first refers to scientific initiation research with five undergraduate students, three from the Nursing course and two from the Psychology course; 2 ) the second refers to periodic meetings for the study and discussion of PICs from the perspective of assistance/care, management, social participation and teaching/training, initially carried out only with undergraduate students and, currently, with the participation of professionals health, constituting a study group of PICs as knowledge, practices and health policies; and 3) the third refers to a proposal to experience the PICs together with SUS health professionals in the different municipalities. Regarding this proposal, it is worth mentioning that, even in the face of the COVID-19 pandemic, care and self-care resources with PICs are being made available in virtual environments via Facebook, Instagram and YouTube. That is, this activity has become an extension activity, and its dynamics of operation take place in a shared, horizontal and collective perspective between undergraduate students, the articulators of DRS III and the teacher.

\section{Extension experience}

We start here from the understanding of university extension as an educational and scientific process that produces knowledge 
that is built on the mutual relationship between society and university. This knowledge is transformative since it occurs through the exchange of popular and academic knowledge ${ }^{(9)}$. It is in this sense that we have built our extension activities with the insertion of integrative practices.

In the field of women's and children's health, the activity of conversation circles in the postpartum period has been developed since 2016 in the context of a Family Health Unit located in a peripheral neighborhood. The rounds happen on babies' consultation days. In the first meeting, the demands and topics of interest that women would like to share are raised. The meeting takes place with an opening song, development of the conversation circle and a final activity proposal. Among these activities, it is possible to make chamomile pillows to relieve colic in babies in the first months of life; self-massage for mothers combined with aromatherapy; and Shantala, which we will focus on in this report.

Shantala, a baby massage technique originating in India, takes place on a specific day when the theme of the conversation wheel goes in the direction of affective exchanges, the importance of touch and the way in which babies perceive the world in the first months of life. Participants are invited to share about their daily life with baby care and touch and massage. Next, we have the specific conversation about Shantala and the invitation to perform the massage technique in practice. With soft music in the background and the certification that the environment is comfortable for babies, the step by step is done, but without a strict sequence, with respect and attentive look the time of each baby, mother, father, family member who participate in the meeting. Crying babies are welcomed; those who are hungry, breastfed; many sleep during the massage, and the environment is charged with tranquillity.

Still in the field of women's health, together with the work of an interdisciplinary team of teachers, health professionals and students, the project of health care for women in situations of Street. In this context, the practice of aromatherapy was inserted. According to the MS, it is the constituent practice of an integrative therapeutic system that uses essential oils extracted from different plant structures, which have the action, among many, of recovering the balance and harmony of the organism aiming at promoting physical and mental health.

This practice was presented to the participants during the conversation: they were invited to choose one of the essential oils taking into account the identification and the therapeutic potential. Then, the oil was diluted and applied using the selfmassage technique. The participants reported the practice as a time to look at themselves. During a meeting on violence against women, the same strategy was used with university cleaning employees, from a third-party company. After the conversation about violence, we proceeded to practice with aromatherapy. At the end, the participants asked when there would be another meeting like that.

It is also worth mentioning the experiences with the extension activities "Integrality in health: conversation and care based on Traditional Chinese Medicine (TCM)", still in progress, in which, in addition to the dialogues about TCM and acupuncture, there were auriculotherapy treatments to SUS professionals from three different services: an FHS, a Basic Health Unit and a specialty clinic. The calls were made in the respective services. The offer of auriculotherapy also covered the UFSCAR's internal community (civil servants and, predominantly, undergraduate students) and the external community (SUS users). The services were given at the Health School Unit. This activity had good acceptance, a lot of demand and has been well evaluated by the people served.

\section{Reflecting the limits, achievements and challenges regard- ing the experience}

In teaching experiences, as limits, one can point out specific activities with PICs in undergraduate subjects. A study on such practices in nursing has shown that few Brazilian institutions of higher education offer disciplines related to them, and those that offer are in the form of an optional discipline. Still, the authors point out that, although PICs are recognized in Brazil, their lack of teaching at undergraduate level makes the number of professionals insufficient ${ }^{(8)}$.

In this sense, among the challenges that arise, there is a need to transform specific activities into continuous activities, institutionalizing the integration of PICs with different disciplines, including the insertion of content related to them in the teaching plans of the respective disciplines, the that collaborates to effect a more integrated curriculum in undergraduate Nursing. On the other hand, the experiences with the PICs in different disciplines signal their integration, recognition and appreciation, with openness to their interdisciplinary interface with nursing. Here, it is worth thinking about the educational institution in parallel with the health institutions. In this analysis, the institutional daily life stands out as a space for the production of new forms of social action in health, in the direction of materializing comprehensiveness in health care and care as a principle and right, and not merely a place for checking ideas ${ }^{(4)}$.

University extension as a form of social approximation and, thus, contact with local demands moves the university towards recognition and connection with this reality. It is important to take into account here the historical and political moments and the interests that reverberate in doing inside and outside the university. The lack of "looking out" and the scarcity of resources to conduct extension activities are some of the obstacles to the continuity and execution of extramural projects, which are also due to the exacerbated valuation of academic production resulting from research. In the logic of this productivist culture, the evaluation of the teacher-nurse and the teacher-researcher aims to meet the quantitative criteria imposed by the managerial model, which has been consolidated in a very perverse way and has motivated teachers-nurses to make their teaching choices based on managerial impositions to the detriment of choices based on dialectical, critical and emancipatory perspectives ${ }^{(10)}$.

Even with this scenario, the PICs are shown within the extension's proposals as practices of care with the capacity for welcoming, promoting well-being and approximation, establishing intersubjective exchanges and building bonds between all those who participate in different services and in the territories, directly with the families. This analysis confirms the emphasis on understanding everyday life as a social locus in which different social relationships take place, the life experiences of people individually 
or in specific groups, collectivities and institutions ${ }^{(4)}$. Hence the need to reinforce the importance of social reach via extension and the consequent reaffirmation of this university commitment.

In the scope of the research, the PICs carry the dialogical possibility between cultures and perspectives, in the way of understanding the different forms of the health-disease-care process. In this sense, the approach of these practices allows the breadth of knowledge to break with a production based on Western science that is still hegemonic. This reflection is in line with the critical perspective towards relativizing biomedical hegemony and opening up to include other rationalities present in the health field ${ }^{(7)}$. Legitimizing the research field in this theme is a constant challenge. The insertion of PICs as a legitimate scientific field indicates a path of exchanges and possibilities based on building together through participatory research that generates changes.

The PICs corroborate the feasibility of working the teachingresearch-extension tripod in an inseparable way and thus favor the construction of new knowledge, the expansion of scientific knowledge and the recognition of other forms of care for the professional practice of nursing, in the direction of a holistic and vitalistic understanding in the field of health. Thinking about this whole set in the training process indicates the development of a relevant and differentiated education system, which also refers to the Nightingalean legacy ${ }^{(3)}$.

Within the field of health, in the theme of PICs, we still have difficulty in dealing with and facing cultural issues and the predominant valuation of the biomedical model. In these comings and goings, facing the adversities of daily life, we resist when we see the impact and social return that these actions allow. We have as a great challenge the continuity of activities, the construction of interdisciplinary partnerships and with services to strengthen these actions.

\section{Study limitations}

A limitation is the need to deepen the specificities of the different PICs in care, teaching and research.

\section{Contributions to the nursing area}

This experience report has the potential to contribute in the nursing field as it marks the interface between PICs and nursing as a profession and science since its precursor, Florence Nightingale, and gives visibility to these therapeutic approaches in the fields of teaching, research and extension. You can also collaborate for future initiatives and studies in the area.

\section{FINAL CONSIDERATIONS}

Analyzing the experience of implementing PICs in the scope of teaching, research and extension in an undergraduate Nursing course meant recognizing the advances, invisibilities and barriers present in this process. Currently, nursing care through PICs is an expression of Florence's avant-garde legacy, celebrated in this bicentennial, and highlights the need to reflect on the slow process of conquests so far, to overcome the limits and challenges present, in the sense to legitimize and institutionalize these practices in university education, in SUS health services and in the set of public health policies in the country. The interaction of PICs in nursing and their insertion in teaching, research and extension corroborate holistic care, favor the construction of scientific knowledge in the area, requalify professional training and can contribute to the consolidation of an integral model of care in SUS in the direction access and comprehensiveness.

\section{REFERENCES}

1. Ehrenreich B, English D. Witches, Midwives \& Nurses: a history of women healers witches, midwives \& nurses: a history of women healers. New York: The Feminist Press; 1973.

2. Frello AT, Carraro TE. Contribuições de Florence Nightingale: uma revisão integrativa da literatura. Esc Anna Nery. 2013;17(3):573-9. https:// doi.org/10.1590/S1414-81452013000300024

3. Figueiredo MAG, Peres MAA. Identidade da enfermeira: uma reflexão iluminada pela perspectiva de Dubar. Rev Enf Ref. 2019;serIV(20):149-154. https://doi.org/10.12707/RIV18079

4. Pinheiro R, Luz MT. Práticas eficazes x modelos ideais: ação e pensamento na construção da integralidade. In: Pinheiro R, Mattos RA (Eds.). Construção da integralidade: cotidiano, saberes e práticas em saúde. Rio de Janeiro: ABRASCO, 2010. 7-34 p.

5. Nightingale F. Notas sobre enfermagem: o que é e o que não é. São Paulo: Cortez; 1989.

6. World Health Organization (WHO). Traditional Medicine Strategy 2014-2023 [Internet]. Geneva: WHO; 2013 [cited 2020 Apr 15]. 73 p. Available from: https://www.who.int/medicines/publications/traditional/trm_strategy14_23/en/

7. Sousa IMC, Hortale VA, Bodstein RCA. Medicina Tradicional Complementar e Integrativa: desafios para construir um modelo de avaliação do cuidado. Ciênc Saúde Coletiva. 2018;23(10):3403-12. https://doi.org/10.1590/1413-812320182310.23792016

8. Salles LF, Homo RFB, Silva MJP. Complementary and integrative practices: situation of their teaching in undergraduate nursing in Brazil. Rev Saúde [Internet]. 2014 [cited 2020 Feb 14];8:3-4. Available from: http://revistas.ung.br/index.php/saude/article/view/2005/1579

9. Serrano RMSM. Conceitos de extensão universitária: um diálogo com Paulo Freire. Grupo de Pesquisa em Extensão Popular. CCS-UFPB [Internet]. 2013 [cited 2020 Feb 14];13(8):1-15. Available from: https://www.ets.ufpb.br/pdf/2013/1\%20Universidade\%20e\%20Sociedade/ US\%2013_Texto\%201\%20Serrano_Conceitos\%20de\%20extensao\%20universitaria.pdf

10. Gatto Jr JR, Fortuna CM, Sousa LA, Santana FR. Nursing professor in higher education: time, money and resistance in the management vision. Texto Contexto Enferm. 2020;29:e20180407. https://doi.org/10.1590/1980-265x-tce-2018-0407 